\title{
GAMBARAN PERILAKU SUAMI DALAM UPAYA PENCEGAHAN HIV/AIDS
}

\author{
Fitri Verona ${ }^{1}$, Yulia Irvani Dewi ${ }^{2}$, Raja Fitrina Lestari ${ }^{3}$ \\ ${ }^{1}$ Mahasiswa PSIK STIKes Hang Tuah Pekanbaru \\ ${ }^{2}$ Staf Pengajar PSIK Universitas Riau Pekanbaru \\ ${ }^{3}$ Staf Pengajar PSIK STIKes Hang Tuah Pekanbaru \\ 'Email : raffadana88@yahoo.com
}

\begin{abstract}
HIV/AIDS is ranked as the fourth leading cause of death in adults from all over the world. Generally, the most transmission of HIV infection are occurred by sexual contact with husband, contaminated syringe, and perinatal transmission of HIV. The objective of these research was to knew the description of husband's behavior towards HIV/AIDS prevention efforts in the Working Area of the Labuh Baru Timur Payung Sekaki Pekanbaru. The study was a quantitative research with simple descriptive design. As the sample, a total of 73 respondents were obtained using purposive sampling technique. Given questionnaire which had been tested for validity and reliability, the results showed that the level of husband's knowledge about HIV/AIDS prevention efforts reached 37 (50.7\%) participants, the husband's positive attitude were 43 (58.9\%) participants and good practices of the husband were as many as 40 (54.8\%) participants. Furthermore, the husbands are encouraged to be able to play an active role in conducting HIV/AIDS prevention efforts by getting more information through joining the health programs about HIV/AIDS and doing prevention efforts in accordance with the program has been already determined.
\end{abstract}

Keywords $\quad$ : HIV/AIDS, Husband, Prevention Efforts

\begin{abstract}
ABSTRAK
HIV/AIDS menduduki peringkat ke-4 penyebab kematian pada orang dewasa diseluruh dunia.Secara umum jalur transmisi penularan HIV yang paling sering terjadi ialah melalui kontak seksual dengan suami, penularan melalui jarum suntik yang terkontaminasi dan melalui ibu ke janin. Tujuan penelitian ini untuk mengetahui gambaran perilaku suami dalam upaya pencegahan HIV/AIDS di Kelurahan Labuh Baru Timur Kecamatan Payung Sekaki. Penelitian ini adalah penelitian kuantitatif dengan design deskriptif sederhana. Jumlah sampel sebanyak 73 responden yang diambil secara purposive sampling. Alat ukur yang digunakan adalah kuisioner yang telah diuji validitas dan realibilitas. Hasil penelitian didapatkan tingkat pengetahuan suami dalam upaya pencegahan HIV/AIDS adalah cukup sebanyak 37 orang $(50,7 \%)$, sikap suami positif sebanyak 43 orang $(58,9 \%)$ dan praktik atau tindakan suami adalah baik sebanyak 40 orang $(54,8 \%)$. Diharapkan para suami untuk dapat berperan aktif dalam melakukan upaya pencegahan HIV/AIDS dengan menambah wawasan dan informasi dengan mengikuti penyuluhan dan melakukan upaya pencegahan sesuai dengan program yang sudah ditentukan.

Kata Kunci : HIV/AIDS, Suami, Upaya pencegahan
\end{abstract}

PENDAHULUAN

Beberapa infeksi dapat ditularkan melalui

hubungan seksual, salah satu infeksi yang 
berbahaya dan dapat menyebabkan kematian ialah HIV/AIDS. HIV adalah singkatan dari "Human Immunodeficiency Virus". HIV dapat menyebabkan Acquired Immunodeficiency Syndrome (AIDS) yang menyerang sel darah putih sehingga dapat merusak sistem kekebalan tubuh manusia. Berdasarkan United Nations Programme on HIV/AIDS (UNAIDS) global statistic bahwa prevalensi HIV/AIDS di dunia tahun 2016 mencapai 2 juta penderita. HIV/AIDS menduduki peringkat ke 4 penyebab kematian pada orang dewasa diseluruh dunia. HIV/AIDS telah menyebar keseluruh dunia dan segala lapisan masyarakat dengan cepat.

Data Kementrian Kesehatan Republik Indonesia (2017) angka kejadian HIV/AIDS terus meningkat setiap tahunnya. Pada bulan Januari sampai Maret 2017 tercatat jumlah penderita HIV/AIDS sebanyak 10.376 orang. Berdasarkan jenis kelamin insiden HIV/AIDS pada laki-laki $6.869(66,2 \%)$ lebih banyak dibandingkan perempuan yaitu $3.511(10,4 \%)$. Berdasarkan golongan umur pada tahun 2016 tercatat rentang umur 20-24 tahun sebanyak $593(16,6 \%)$ dan usia 25-29 tahun sebanyak 2.490 atau $69,7 \%$ penderita yang terinfeksi HIV/AIDS. Sedangkan pada tahun 2017 terdapat peningkatan pada usia 20-24 tahun sebanyak $1.823(17,6 \%)$ dan usia 25-29 tahun sebanyak $7.220(69,6 \%)$ yang terinfeksi HIV/AIDS.

Secara umum jalur transmisi penularan HIV yang paling sering terjdi ialah melalui kontak seksual, penularan melalui jarum suntik yang terkontaminasi dan melalui ibu ke janin. Kontak hubungan seksual dan pemakaian narkotika dan obat-obatan secara suntik atau Injection Drug Users merupakan faktor utama penularan HIV/AIDS termasuk di Indonesia (Siregar et al., 2015). Peran dan tanggung jawab perempuan dan laki-laki dalam kesehatan reproduksi adalah sama, namun pada kenyataannya saat ini peran laki-laki masih rendah. Banyak hal yang mempengaruhi rendahnya peran lakilaki seperti minim informasi dan fasilitas pelayanan kesehatan reproduksi bagi lakilaki, faktor sosial budaya serta rendahnya pengetahuan tentang reproduksi dan keadilan gender. Perilaku seksual yang salah dapat menjadi faktor utama tingginya penyebaran virus HIV/AIDS dibidang sosial budaya, perubahan gaya hidup menjadi glamor membuat masyarakat lupa akan adat istiadat dan ajaran agama. Akibatnya, kontrol dalam kehidupan pun seakan sirna, disamping itu adanya budaya berganti pasangan ini merupakan penyebab timbulnya penyakit kelamin yang berujung 
HIV dan AIDS (Noviana, 2013; Siregar et al., 2015).

Hasil survei awal yang dilakukan pada 02 Maret 2018 di Puskesmas Payung Sekaki didapatkan dari Dinas Kesehatan Kota Pekanbaru data terbanyak yang mengkuti pemeriksaan HIV/AIDS terdapat di wilayah kerja Puskesmas Lima Puluh sebanyak 308 orang dan data yang tercatat paling sedikit mengikuti pemeriksaan HIV di wilayah kerja Puskesmas Payung Sekaki sebanyak 3 orang pada kelompok resiko. Mengingat sedikitnya jumlah masyarakat yang mengikuti pemeriksaan HIV di wilayah kerja Puskesmas Payung Sekaki, hal itu mungkin di karenakan masih rendahnya upaya pencegahan dan minimnya informasi terkait HIV/AIDS di wilayah tersebut. Hasil wawancara dengan 4 orang suami di wilayah kerja Puskesmas Payung Sekaki didapatkan bahwa 3 dari 4 orang suami mengatakan untuk mencegah terjadinya penularan HIV/AIDS dengan tidak mendekati dan bersentuhan dengan si penderita.

\section{METODE PENELITIAN}

Penelitian ini adalah jenis penelitian kuantitatif dengan design penelitian deskriptif sederhana, dimana suatu penelitian yang bersifat menggambarkan sebuah fenomena yang menjadi tujuan
Berdasarkan fenomena diatas dapat kita lihat kejadian yang terus meningkat tentu menjadi salah satu tanda semakin maraknya penularan virus HIV/AIDS, dari survei dapat dilihat masih kurang nya informasi terkait HIV/AIDS di wilayah kerja Puskesmas Payung Sekaki. HIV/AIDS merupakan suatu penyakit dengan siklus yang panjang, maka dari itu mencegah penularannya menjadi sangat penting terutama melalui pendidikan kesehatan dan peningkatan pengetahuan yang benar terkait HIV/AIDS. Dari upaya menurunkan resiko penularan untuk mencegah terjadinya infeksi virus HIV/AIDS, peran serta tanggung jawab lakilaki atau suami dalam mencegah penularan infeksi HIV/AIDS sangat penting, dan tingginya jumlah penderita laki-laki dari pada perempuan. Berdasarkan data dan penjelasan diatas peneliti tertarik untuk meneliti tentang "Gambaran perilaku suami dalam upaya pencegahan HIV/AIDS".

penelitian (Notoadmodjo, 2010). Dasar penelitian ini adalah untuk menganalisa gambaran perilaku suami dalam upaya pencegahan HIV/AIDS di Kelurahan Labuh Baru Timur Payung Sekaki Kota Pekanbaru. 


\section{HASIL PENELITIAN}

\section{Analisa Univariat}

Karakteristik Responden

\section{Tabel 1.}

Distribusi frekuensi karakteristik usia responden

\begin{tabular}{lcc}
\hline \multicolumn{1}{c}{ Usia (Tahun) } & Frekuensi & Persentase (\%) \\
\hline $25-30$ & 10 & 13,7 \\
$31-40$ & 50 & 68,3 \\
$41-50$ & 13 & 17,9 \\
\hline Jumlah & $\mathbf{7 3}$ & $\mathbf{1 0 0}$ \\
\hline Pendidikan terakhir & & 78,1 \\
\hline Sekolah Menengah Atas & 57 & 21,9 \\
Perguruan tinggi & 16 & $\mathbf{1 0 0}$ \\
\hline Jumlah & $\mathbf{7 3}$ & \\
\hline Status Pekerjaan & & 32,9 \\
\hline Buruh & 24 & 1,4 \\
Guru & 1 & 46,6 \\
Wirausaha & 34 & 11,0 \\
Wiraswasta & 8 & 4,1 \\
Honorer & 3 & 4,1 \\
Pegawai & 3 & $\mathbf{1 0 0}$ \\
\hline Jumlah & $\mathbf{7 3}$ & \\
& &
\end{tabular}

Berdasarkan tabel diatas menunjukan besar responden bekerja sebagai Wirausaha bahwa sebagian besar responden berusia 31sebanyak 34 orang $(46,6 \%)$.

40 tahun sebanyak 50 orang $(68,3 \%)$.

Mayoritas responden berpendidikan SMA sebanyak 57 orang $(78,1 \%)$, dan sebagian

Pengetahuan suami dalam upaya pencegahan HIV/AIDS

\begin{tabular}{lcc}
\hline Tingkat pengetahuan & Frekuensi & Persentase $(\boldsymbol{\%})$ \\
\hline Baik & 15 & 20,5 \\
Cukup & 37 & 50,7 \\
Kurang & 21 & 28,8 \\
\hline Jumlah & $\mathbf{7 3}$ & $\mathbf{1 0 0}$ \\
\hline
\end{tabular}

Tabel 2.

Distribusi frekuensi tingkat pengetahuan suami 
Tabel 2 menunjukan sebagian besar responden memiliki pengetahuan cukup dalam
Sikap suami dalam upaya pencegahan HIV/AIDS upaya pencegahan HIV/AIDS sebanyak 37

Tabel 3.

Distribusi frekuensi sikap suami

\begin{tabular}{|c|c|c|}
\hline Sikap & Frekuensi & Persentase ( \% ) \\
\hline Positif & 43 & 58,9 \\
\hline Negatif & 30 & 41,1 \\
\hline Jumlah & 73 & 100 \\
\hline
\end{tabular}
suami bersikap positif dalam upaya (58,9\%).

Tindakan suami dalam upaya pencegahan HIV/AIDS

Tabel 4.

Distribusi frekuensi sikap suami

\begin{tabular}{lcc}
\hline Tindakan & Frekuensi & Persentase ( \% ) \\
\hline Baik & 40 & 54,8 \\
Buruk & 33 & 45,2 \\
\hline Jumlah & $\mathbf{7 3}$ & $\mathbf{1 0 0}$ \\
\hline
\end{tabular}

Berdasarkan tabel 4.4 sebagian besar responden memiliki tindakan baik dalam

\section{PEMBAHASAN}

Tingkat pengetahuan suami dalam upaya pencegahan HIV/AIDS

Hasil penelitian menunjukan bahwa responden mempunyai tingkat pengetahuan tinggi sebanyak 15 orang (20,5\%), pengetahuan cukup sebanyak 37 orang $(50,7 \%)$ dan pengetahuan rendah sebanyak 21 orang $(28,8 \%)$. Hal ini terlihat bahwa mayoritas responden memiliki pengetahuan upaya pencegahan HIV/AIDS yaitu sebanyak 40 orang $(54,8 \%)$.

cukup dan rendah dalam upaya pencegahan HIV/AIDS. Hasil penelitian ini sesuai dengan penelitian Yeni (2016) bahwa terdapat hubungan antara pengetahuan suami tentang upaya pencegahan HIV/AIDS. Penelitian Anggreani (2016), juga menyatakan hal yang sama bahwa terdapat hubungan pengetahuan suami dengan upaya pencegahan HIV/AIDS di Pengasih Kulon Progo Yogyakarta, tingkat 
pengetahuan suami tentang HIV/AIDS paling banyak berada kategori sedang sebanyak 54\%. Menurut Notoatmodjo (2003), pengetahuan merupakan hasil tahu seseorang setelah memperoleh melalui pengindraan, sebagian besar pengetahuan didapat melalui mata dan telinga. Pengetahuan akan menggambarkan perilaku seseorang dalam tindakan pencegahan HIV/AIDS. Apabila pengetahuan baik, maka tindakan pencegahan juga tepat, begitu juga sebaliknya. Dari analisis kuesioner ada beberapa pernyataan yang tidak tepat dijawab oleh responden salah satunya adalah cara penularan HIV/AIDS. Menurut Siregar (2015), cara mencegah penularan HIV/AIDS ialah menggunakan konsep "ABCDE" (Abstinence, Be Faithfull, Condom, Don't use inject drug, Equipment) dimana cara mencegah penularannya dengan tidak melakukan hubungan seksual sembarangan, menggunakan kondom saat berhubungan seksual dan tidak bergantian menggunakan alat seperti jarum suntik, alat potong kuku, atau alat lainnya yang berhubungan dengan darah.

Mayoritas responden penelitian, menjawab benar tentang pencegahan HIV/AIDS dengan setia kepada pasangan (Be Faithfull). Menurut asumsi peneliti hal ini kemungkinan disebabkan oleh tingkat pendidikan suami adalah SMA dan perguruan tinggi, disamping itu juga pengaruh informasi yang didapat dari media tentang HIV/AIDS. Hal ini diperkuat oleh Adnyani (2012), pada penelitian sebelumnya pemberian informasi lewat penyuluhan memang dapat meningkatkan pengetahuan seseorang mengenai cara menghindari terinfeksi dan bahaya penyakit HIV.

\section{Sikap suami dalam upaya pencegahan HIV/AIDS}

Berdasarkan hasil penelitian didapatkan bahwa sikap suami terhadap upaya pencegahan HIV/AIDS sebagian besar bersikap positif yaitu 58,9\% dan sikap negatif sebanyak $41,1 \%$. Sikap positif ini peniliti hubungkan dengan pengalaman pribadi tentang pengetahuan atau informasi yang didapat terkait HIV/AIDS. Menurut teori Maulana (2014), sikap ialah suatu reaksi atau respon yang masih tertutup atas suatu objek. Analisis kuesioner, sebagian besar menyatakan sikap positif dan sudah setuju bahwa setiap orang harus tahu cara mencegah penularan HIV ialah dengan menggunakan kondom dan tidak bergantiganti pasangan ialah sebanyak 58,9\%. Namun demikian sebagian lagi responden memiliki sikap negatif terhadap cara penularan HIV/AIDS sebanyak 41,1\%. Dari penelitian ini menunjukan bahwa semakin 
tinggi tingkat pengetahuan seseorang maka akan berdampak positif terhadap sikap, sebagian besar suami sudah memiliki pengetahuan yang cukup, karena kurangnya paparan terhadap informasi khususnya masalah kesehatan berpengaruh terhadap sikap dan perilaku.

Hal ini sesuai dengan pernyataan Wawan dan Dewi (2011), beberapa komponen yang membentuk sikap yaitu komponen yang berkaitan dengan pengetahuan, pandangan, dan keyakinan yaitu hal-hal yang berhubungan dengan bagaimana seseorang berfikir sesuatu terhadap suatu sikap. Hal ini didukung Juliastika (2011), bahwa seseorang yang memiliki pengetahuan dapat merubah sikap dan perilaku seseorang dalam upaya pencegahan HIV/AIDS. Penelitian lain oleh Umam (2015), menyatakan sikap seseorang terhadap HIV/AIDS dapat dipengaruhi beberapa hal seperti pengalaman pribadi, media massa, pengaruh orang lain yang dianggap penting, pengaruh kebudayaan, lembaga pendidikan, dan lembaga agama.

\section{Praktik atau tindakan suami dalam upaya pencegahan HIV/AIDS}

Berdasarkan hasil penelitian sebagian besar tindakan suami dalam upaya pencegahan HIV/AIDS adalah baik sebanyak 54,8\% dan buruk 45,2\%. Hal serupa juga ditemukan dalam penelitian Arwinda (2014), bahwa sebagian besar tindakan responden terhadap upaya pencegahan HIV/AIDS dalam kategori baik dengan mengikuti penyuluhan tentang HIV/AIDS. Menurut Notoatmodjo (2003), bahwa suatu sikap belum tentu terwujud dalam sebuah tindakan. Dari analisis kuesioner sebagian besar responden menjawab selalu setia dan tidak bergantiganti pasangan dalam melakukan hubungan seksual untuk mencegah terjadinya penularan HIV/AIDS, dengan demikian salah satu upaya pencegahan berdasarkan cara penularan sudah dipraktikan dengan baik. Hal itu diperkuat oleh penelitian Asti (2014), terkait perilaku dimana faktor terwujudnya suatu sikap agar menjadi sebuah tindakan diperlukan faktor pendukung seperti fasilitas dan dukungan dari pihak lain seperti keluarga, faktor lingkungan, kelompok teman sebaya, tingkat pendidikan, dan akses informasi yang belum sampai kewilayah mereka dapat menjadi faktor penyebab kurangnya kesadaran akan bahaya HIV/AIDS. Hasil analisis kuesioner sebagian besar responden sebanyak 46 orang $(63,0 \%)$ tidak pernah menggunakan kondom saat berhubungan seksual dengan istri, kemungkinan hal tersebut dikarenakan suami merasa yakin sudah setia kepada istri 
dan tidak berganti-ganti pasangan. Hal ini juga diperkuat dengan penelitian Sianturi (2012), tentang hubungan faktor pendukung dan penguat tindakan penggunaan kondom pada WPS untuk pencegahan HIV/AIDS yang menyatakan bahwa penggunaan kondom lebih sering ditemukan pada kelompok yang memiliki pengetahuan komprehensif.

Hasil penelitian ini menunjukan beberapa dari responden memiliki upaya yang rendah dalam melakukan tindakan pencegahan HIV/AIDS, dari analisis kuesioner sebagian besar sebanyak 95,8\% responden kadang-kadang dan tidak pernah melakukan tes HIV serta mengikuti penyuluhan terkait pencegahan HIV/AIDS. Asumsi peneliti terkait hal ini kemungkinan disebabkan karena mayoritas responden bekerja sebagai Buruh dan Wirausaha yang dituntut untuk dapat memberikan waktu, tenaga dan fikiran dalam mencapai hasil yang diinginkan. Hasil penelitian ini diperkuat oleh penelitian Carmelita (2017), bahwa seseorang yang memiliki tuntutan dalam pekerjaan mempunyai waktu terbatas untuk dapat melakukan tindakan upaya pencegahan seperti mengikuti skrining IMS. Hal itu sesuai dengan teori tentang praktik atau tindakan dapat dihubungan dengan beberapa faktor pendukung, diantaranya ialah sumber informasi atau pengetahuan, sikap, lingkungan dan sumber daya yang meliputi fasilitas dan pelayanan kesehatan (Notoatmodjo, 2010). Penelitian lain oleh Rishadi, dkk (2012), adanya ketidaksesuaian sikap terhadap upaya pencegahan HIV/AIDS disebabkan pengetahuan tentang HIV yang dimiliki seseorang tidak sejalan dengan sikap dan praktik upaya dalam merubah tindakan atau tingkah laku seseorang.

Penelitian lain oleh Sitepu (2012), menjelaskan bahwa terdapat pengaruh antara motivasi seseorang dengan pemanfaatan klinik HIV/AIDS untuk melakukan pemeriksaan. Motivasi merupakan salah satu faktor yang dominan mempengaruhi pelayanan VCT karena motivasi dapat diikuti dengan tindakan. Diperkuat oleh penelitian Moniroh (2016), bahwa adanya program pencegahan dan penanggulangan yang dilaksanakan Yayasan Vesta Indonesia adalah dengan melakukan VCT Mobile dan strategi ABCDE guna menjangkau kelompok-kelompok laki-laki berhubungan seks dengan laki-laki atau LSL.

\section{Kesimpulan}

Berdasarkan hasil penelitian yang dilakukan di kelurahan Labuh Baru Timur Kecamatan Payung Sekaki Kota Pekanbaru, dapat disimpulkan Gambaran Perilaku Suami 
Dalam Upaya Pencegahan HIV/AIDS ialah sebagian besar dari responden berusia 31-40 tahun sebanyak 50 orang $(68,3 \%)$, jenjang pendidikan terakhir SMA sebanyak 57 orang $(78,1 \%)$, dan sebagian besar dari status pekerjaan suami adalah wirausaha sebanyak 34 orang $(46,6 \%)$. Tingkat pengetahuan suami tentang HIV/AIDS sebagian besar adalah cukup yaitu sebanyak 50,7\%, sikap suami dalam upaya pencegahan HIV/AIDS adalah positif sebanyak $58,9 \%$ dan praktik atau tindakan suami dalam melakukan upaya pencegahan HIV/AIDS adalah baik sebanyak $54,8 \%$.

\section{Saran}

Diharapkan bagi peneliti selanjutnya meneliti tentang bagaimana perilaku suami dalam upaya pencegahan HIV/AIDS setelah mendapatkan edukasi kemudian dapat dihubungan dengan faktor lain yang dapat mempengaruhi perilaku tersebut.

\section{Daftar Pustaka}

Carmelita P, Deaselia. (2017). Analisa faktor-faktor yang berhubungan dengan praktik skrining IMS oleh lelaki seks lelaki (LSL) sebagai upaya pencegahan penularan $H I V$ (Studi kasus pada semarang gaya community). Jurnal kesehatan masyarakat, 5(3).
Hutapea, Ronald. (2011). AIDS \& PMS dan pemerkosaan. Jakarta; Rineka Cipta

Kementrian Kesehatan Republik Indonesia. Profil Kesehatan Indonesia 2016. Jakarta. Kementrian Indonesia 2017.

Muniroh, Arofatum. (2016). Strategi pencegahan peningkatakan resiko penularan HIV/AIDS pada LSL (Laki-laki berhubungan seks dengan laki-laki) oleh Yayasan Vesta Indonesia di Yogyakarta. Fakultas Dakwah dan Komunikasi Universitas Islam Negeri Sunan Kalijaga Yogyakarta.

Notoatmodjo, Seokidjo. (2003). Ilmu kesehatan masyarakat prinsipprinsip dasar. Rineka Cipta; Jakarta.

Rishadi A, dkk. (2012). Hubungan pengetahuan dan dikao calon tenaga kerja Indonesia dengan upaya pencegahan HIV dan AIDS di BP3TKI Makassar. http://Frepository.unhas.ac.id/Fbitst reamFhandleF/123456789/hubunga $\underline{n}$ pengetahuan dan sikap calon tenaga kerja Indonesia dengan upaya pencegahan hivdan aids.pdf.bmk diakses pada tanggal 31 Agustus 2018.

Sianturi, Sutri Ana. (2012). Hubungan faktor predisposisi, pendukung, dan 
penguat dengan tindakan pengguanaan kondom pada WPS untuk pencegahan HIV/AIDS di Kabupaten Serdang Begadai. Medan; Universitas Sumatra Utara.

Siregar,. Et al. (2015). Buku Ajar HIV dan AIDS. Unri Press

Sitepu, M. (2012). Pengaruh pengetahuan persepsi dan motivasi PSK terhadap pemanfaatan pelayanan klinik
IMS/HIV-AIDS dipuskesmas Bandar Baru. Medan; Universitas Sumatra Utara.

Umam, Husnul., Irvani Dewi, Yulia., Elita, Yeni. (2015). Identifikasi karakteristik orang resiko tinggi HIV dan AIDS tentang program pelayanan voluntary counseling and testing (VCT). Riau; Universitas Riau, 2(01). 